\title{
In vitro Anticancer Property of Yellow Pigment from Streptomyces griseoaurantiacus JUACT 01
}

\author{
Kuruvalli Prashanthi $^{*}$, Sandeep Suryan ${ }^{2}$ and Kilinger Nadumane Varalakshmi ${ }^{1}$ \\ ${ }^{I}$ Department of Biotechnology; Centre for Post Graduate Studies; Jain University, Jayanagar, Karnataka - India. \\ ${ }^{2}$ Centre for Emerging Technologies; Jain University; Jain Global Campus; Kanakapura Taluk, Karnataka - India
}

\begin{abstract}
Despite the complications in isolation of pigments, microbial pigments are increasingly gaining the attention of researchers because of their broad range therapeutic potentials, especially against cancer. In this study the cytotoxic and anti proliferative potentials of yellow pigment from Streptomyces griseoaurantiacus JUACT 01 isolated from soil are investigated. The effect of pigment treatment on the growth and proliferation of in vitro cervical cancer cells (HeLa) and liver cancer cells (Hep G2) was tested by various methods. Significant cytotoxicity was observed with IC ${ }_{50}$ values as low as 1.5 and $1.8 \mu \mathrm{g} / \mathrm{mL}$ with HeLa and Hep G2 cells respectively. The pigment exhibited non toxic effects on human lymphocytes. Decrease in the number of viable cells, presence of apoptotic bodies, nuclear condensation and sheared DNA were distinctly observed in pigment treated cancer cells. The biochemical test and the infrared (IR) spectra indicated the probable carotenoid presence in the TLC purified pigment fraction. High Performance Liquid Chromatography (HPLC) analysis of the TLC purified yellow pigment showed a single large peak with a retention time of $9.90 \mathrm{~min}$ and $\mathrm{m} / \mathrm{z}$ value corresponding to the peak was found to be 413.22 showing $100 \%$ relative abundance.
\end{abstract}

Key words: Anticancer activity, ESI-MS, Fluorescence microscopy, Streptomyces griseoaurantiacus JUACT 01, yellow pigment

\section{INTRODUCTION}

"Chemotherapy "defined as use of chemicals to treat disease is one of the most popular modes of treating cancer (Ferlay et al. 2013). The age-old practice of surgery and radiotherapy became unsatisfactory with the increase in major ramifications with cancer. Search for novel drugs has become a priority goal for cancer therapy, due to the fast development of resistance to multiple chemotherapeutic drugs. A large number of anticancer compounds are natural products or their derivatives, mainly produced by microorganisms. Actinomycetes which are filamentous gram positive bacteria are popularly known as the producers of large number of bioactive molecules (Berdy 2005). Actinomycetes and, in particular the genus Streptomyces, have been well known during the last seventy years as prolific producers of new bioactive compounds. These bioactive molecules are extensively being used as antibiotics, antitumor agents, immunosuppressive agents and enzymes (Solanki et al. 2003). Specifically, bacteria of this group produce antitumor compounds such as anthracyclines (aclarubicin, daunomycin and doxorubicin), glycopeptides (bleomycin and actinomycin D), aureolic acids (mithramycin), enediynes (neocarzinostatin), antimetabolites (pentostatin), carzinophilin, mitomycins and others (Olano et al. 2009). Even the pigments of

*Author for correspondence: kprashanthirao@gmail.com 
actinomycetes have bioactive potentials (Soliev et al. 2011). In the current study, we attempted to isolate a yellow pigment from a soil actinomycete and evaluate its anticancer potentials.

\section{MATERIAL AND METHODS}

\section{Isolation and identification}

Soil samples for isolation of pigmented actinomycetes were collected from a variety of sources like rhizosphere of orchids, leaf litter soil, garden soil etc. Serial dilution and spread plate technique using Starch Casein Nitrate Agar (SCNA) media containing fluconazole $(25 \mathrm{mg} / \mathrm{L})$ and tetracycline $(50 \mathrm{mg} / \mathrm{L})$ were used for selective isolation of the actinomycetes. Preliminary identification was based on the microscopic and cultural observations as per the International Streptomyces Project (ISP) (Shirling and Gottlieb 1966). Molecular identification was performed by sequencing the conserved 16S ribosomal RNA gene encoding DNA fragment of $1500 \mathrm{bp}$, obtained after specific PCR amplification using the universal primers (Schwieger and Tebbe 1998). The sequence obtained was compared with similar sequences retrieved from the GenBank nucleotide sequences database (Altschul et al. 1990). The sequence was deposited in GenBank with the accession number KJ774106. A distance matrix tree was constructed using the neighborjoining method (Saitou and Nei 1987), and the topology of the phylogenetic tree was built by bootstrap analysis (Felsenstein 1985) using MEGA6.2 (Tamura et al. 2011).

\section{Media optimization and pigment extraction}

Yellow pigment producing Streptomyces griseoaurantiacus JUACT 01 was selected for the study. The best ISP media suited for maximum pigment yield was identified by growing the organism in all the seven ISP media (Shirling and Gottlieb 1966). The pigment was extracted by solvent extraction as previously reported (Selvameenal et al. 2006) with minor modifications. Instead of wheat flakes, $10 \mathrm{gm}$ of oat flakes were used as substrate in the solid state fermentation process. Ethyl acetate and methanol were used for pigment extraction from Streptomyces griseoaurantiacus JUACT 01 cultured under submerged fermentation. The biomass was homogenised using the solvents and filtered. The filtrate containing the pigment was dried under vacuum conditions. The dry pigment was re-dissolved in a suitable solvent for spectrophotometric quantification. Pre coated silica TLC sheets (60 F 254, Merck) were used to fractionate the pigment. A number of solvents like n-hexane, chloroform, ethyl acetate, acetone, methanol, water and acetonitrile in different proportions were tested as solvent system. After activating the TLC sheet at $100^{\circ} \mathrm{C}$ the extracts were spotted half centimetre above the bottom edge and allowed to run till the solvent system reaches half centimetre below the top edge. The separated fractions were detected by observing the TLC sheet under UV - light and then exposing the sheet to iodine vapour. As we were interested in the pigment fraction, the coloured fraction was visible to the naked eye. The distance moved by each fraction from the origin was measured and corresponding Rf values were calculated (Kirchner et al. 1951).The separated fractions were recovered by scraping the spot on the silica sheet and suspending in suitable organic solvent. The silica was removed by centrifugation and the supernatant organic solvent was evaporated to obtain the purified fraction (Kirchner 1973). Further, to detect the presence of carotenoids biochemical test was conducted as illustrated by Ajayi et al. (2011). The purified pigment was analysed using Attenuated Total Reflectance Infra Red (ATR-IR) (Bruker Alpha ECO-ATR spectrometer) to obtain the functional group absorption frequencies (Coates 2000).

\section{Screening for anticancer activities}

The effect caused by the TLC purified yellow pigment on the growth and proliferation of Human cervical cancer cell line (HeLa) and Human liver cancer cell line (HepG2) was tested by: 3-(4, 5dimethylthiazol-2yl)-2, 5-diphenyl tetrazolium bromide) (MTT) cell viability assay, caspase activity assay, lactate dehydrogenase (LDH) activity assay, DNA fragmentation assay, flow cytometry and trypan blue cell counting assay.

MTT assay was performed with HeLa, Hep G2 and human lymphocytes. The cells were seeded in 96-well flat-bottom microtiter plates and incubated in a $\mathrm{CO}_{2}$ incubator at $37^{\circ} \mathrm{C}$ with $5 \% \mathrm{CO}_{2}$ and $95 \%$ air overnight for cell adhesion. Different concentrations of the pigment $(2.5,5,10$ and 20 $\mu \mathrm{g} / \mathrm{mL}$ ) were added in quadruplicates and incubated for 24, 48 and $72 \mathrm{~h}$. Following incubation, $100 \mu \mathrm{L}$ of MTT solution was added. The culture was then incubated for $3 \mathrm{~h}$ in a dark. 
After the incubation period the supernatant was aspirated and $100 \mu \mathrm{L}$ of DMSO was added to dissolve the formazan. The absorbance was recorded at $540 \mathrm{~nm}$ with the help of an ELISA plate reader (Mosmann 1983). The percentage viability was calculated using the following formula:

Percentage viability $(\%)=\left(\mathrm{A}_{540}\right.$ of the test sample $)$ / $\left(\mathrm{A}_{540}\right.$ of the control $) \times 100$

The effect of pigment on normal cells was tested by treating the yellow pigment on healthy lymphocytes. Lymphocyte isolation was performed based on the method described by Nadumane et al. (2013) and cytotoxicity was tested by MTT assay as mentioned above.

\section{DNA fragmentation analysis}

For analysing the DNA fragmentation in the treated cells, TLC purified pigment was added to the monolayer of HeLa and Hep G2 cells grown in $25 \mathrm{~cm}^{2}$ flasks, in order to obtain a final concentration of $10 \mu \mathrm{g} / \mathrm{mL}$. After $24 \mathrm{~h}$ of incubation, the cells were harvested, lysed and DNA was isolated using Mammalian Genomic DNA isolation Kit (HiMedia Ltd). The isolated DNA was electrophorosed using $0.8 \%$ agarose gel containing Ethidium Bromide and visualised with the help of gel documentation system (Herolabs, Germany) (Sambrook et al. 1989).

\section{LDH activity assay}

Cytotoxicity caused by the pigment was analysed by measuring the activity of the cytosolic enzyme Lactate dehydrogenase (LDH). Cancer cells treated with the pigment fraction $(10 \mu \mathrm{g} / \mathrm{mL})$ for $24 \mathrm{~h}$ were used and assayed for LDH activity as per manufacturer's instructions using Cytoscan LDH Assay kit (G Biosciences Ltd, USA). The OD was measured at $490 \mathrm{~nm}$ using a micro-plate reader and the percentage cytotoxicity was calculated.

\section{Caspase activity assay}

The effect of the pigment on the induction of apoptosis in the cancer cells was determined by measuring the activity of caspases using CasPASE ${ }^{\mathrm{TM}}$ Apoptosis Colorimetric Assay kit (G Biosciences Ltd, USA). The OD was measured at $405 \mathrm{~nm}$ using micro-plate reader. Comparison of the optical density from the pigment treated sample with a control sample determines the foldincrease in the caspase activity.

\section{Fluorescence microscopic analysis}

Cells morphology is one of the indicative factors to assign the healthy status of the cell. The cells treated with pigment for $24 \mathrm{~h}$ were harvested by centrifugation and stained with $\mathrm{AO} / \mathrm{EB}$ dye (each $100 \mathrm{mg} / \mathrm{L}$ in PBS). The cells were examined and photographed using a fluorescence microscope.

\section{Flow cytometry}

The effect of pigment fraction on cell cycle was determined by Flow cytometry with PI Staining (Pozarowski et al. 1995).The treated HeLa cells were harvested by trypsinisation and centrifugation. Required quantity of PBS was added to the cell pellet to obtain a final concentration of $1-2 \times 10^{6}$ cells $/ \mathrm{ml}$. The cells were fixed in chilled $70 \%$ ethanol at $4^{\circ} \mathrm{C}$ overnight. After incubation, cells were centrifuged again at $5000 \mathrm{rpm}$ for $10 \mathrm{~min}$ and washed twice with PBS. Cells were resuspended in $1 \mathrm{~mL}$ of PBS and in ribonuclease $(100 \mu \mathrm{g} / \mathrm{mL})$. Then cells were resuspended in staining solution $\left[\begin{array}{lll}50 & \mu \mathrm{g} & / \mathrm{mL}\end{array}\right.$ propidium iodide, 30 units $/ \mathrm{ml}$ RNase, $4 \mathrm{mM} \mathrm{l^{-1 }}$ sodium citrate, and Triton $\mathrm{X}-100(\mathrm{pH} 7.8)]$ and incubated at $37^{\circ} \mathrm{C}$ for $15 \mathrm{~min}$. After incubation in the dark, fluorescence-activated cells were sorted in a FACScan flow cytometer (equipped with a $488 \mathrm{~nm}$ argon laser), and the data was analyzed using MACS Quant analyser.

\section{HPLC and ESI MS}

HPLC analysis was performed using Waters HPLC system with 2487 dual $\lambda$ UV detector, 1525 binary pump, and C-18 octadecylsilane (ODS) column $(150 \times 4.6 \mathrm{~mm})$ with $5,0 \mu \mathrm{m}$ particle size. The separation was performed using isocratic elution with Methanol and water in a ratio of 1:2 as solvent system and flow rate as $1 \mathrm{~mL} / \mathrm{min}$. Prior to injection, the sample and the solvent system were filtered through $0.22 \mu \mathrm{m}$ polyvinylidene fluoride (PVDF) filters (Snyder et al. 2012). The Electro spray Ionisation Mass Spectrometry (ESIMS) analysis was performed using a single quadrupole mass spectrometer (Hewlett Packard HP 1100 MSD series). Spectra were acquired over the mass range $50-1300 \mathrm{~m} / \mathrm{z}$.

\section{Statistical analysis}

All the experiments were performed in triplicates and repeated twice, to check the reproducibility and confirm the results. The results were calculated as mean \pm standard error (SE) values. 
Statistical significance was calculated using one way analysis of variance (ANOVA) to test the null hypothesis. Duncan's multiple range test (DMRT) was done to compare the sample means. The data were considered significantly different from each other when significance level was $\mathrm{P}<0.05$ (Gomez and Gomez 1984).

\section{RESULTS AND DISCUSSION}

While screening the pigments extracted from actinomycetes for their anticancer property, an actinomycete strain JUACT 01was identified, which produced a yellow pigment with strong anticancer activity against the human cervical cancer cell line, HeLa and human liver cancer cell line, HepG2. Soil has always been an excellent microbial source for a variety of common as well as uncommon microbes. Fundamental microbiological investigations along with sequence analysis are the methods adopted effectively for characterization as it gives an undoubted identification relative to the knowledge of the existing organisms. Based on the preliminary morphological and phenotypic observations, the yellow pigment producing organism was identified as a member of Streptomyces species (Fig. 1).

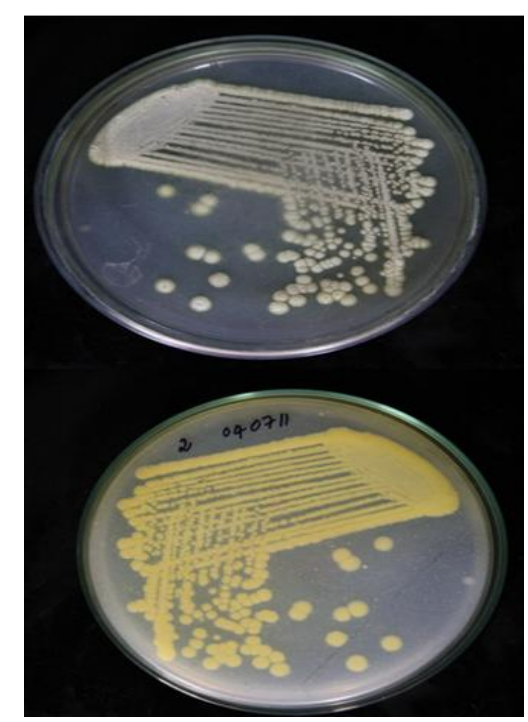

Figure 1 - Pure culture of pigment producing Streptomyces griseoaurantiacus JUACT 01 grown on SCNA agar.

The16S ribosomal RNA encoding gene sequence analysis with sequences of representatives of
Streptomycetaceae family confirmed that the unknown isolate belonged to genus Streptomyces and the highest 16S rRNA gene sequence similarity was found with Streptomyces griseoaurantiacus strain NBRC 15440 (100\%). The sequence was submitted to GenBank database with accession number KJ774106. The organism was identified as Streptomyces griseoaurantiacus JUACT 01.This was also confirmed by Phylogenetic analysis performed using NeighborJoining method. Based on the phylogenetic tree the strain JUACT 01 showed highest affinity with Streptomyces griseoaurantiacus by a $100 \%$ bootstrap level and loosely related to others (Fig. 2).

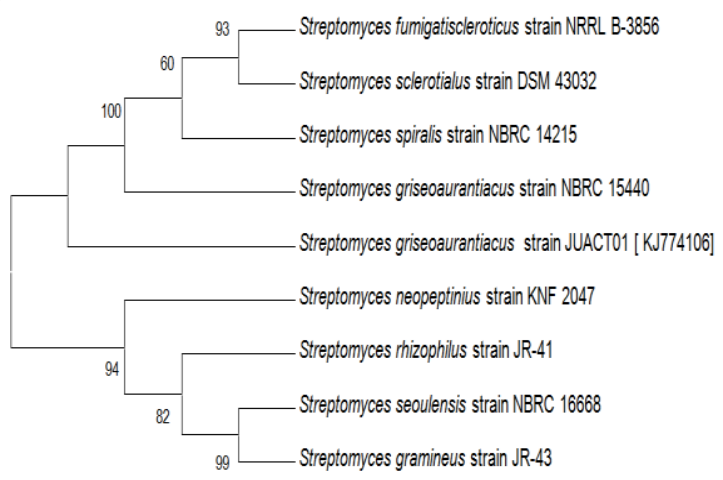

Figure 2 - The evolutionary history was inferred using the Neighbor-Joining method. The optimal tree with the sum of branch length $=0.06865153$ is shown. The percentage of replicate trees in which the associated taxa clustered together in the bootstrap test (1000 replicates) are shown next to the branches. The evolutionary distances were computed using the Maximum Composite Likelihood method and are in the units of the number of base substitutions per site.

The pigment extracted using ethyl acetate as the solvent system was analysed by scanning the absorbance with UV-VIS spectrophotometer and the absorbance peak was observed at $410 \mathrm{~nm}$. In order to select reproducible procedures and stable properties for characterization of Streptomyces species, certain media were developed for International Streptomyces Project (ISP) (Shirling and Gottlieb 1996). These are ISP1-7 media. Amount of pigment production varied with different ISP media in which JUACT 01 was grown. The pigment production was highest with ISP5 media giving $4.13 \mathrm{~g} / \mathrm{L}$. It was also found that the pigment production was negligible in ISP2, 
ISP3 and ISP4 media. Neither growth nor pigment production was seen with ISP7 media. Majority of the microbial secondary metabolite extraction procedures use combination of solvents varying in polarity. This method was selected for separation of the fractions conveniently with higher resolution (Seidel et al. 2005). Methanol and hexane in the ratio of $7: 3$ was found to be the best solvent combination for the separation of the pigment by Thin Layer Chromatography (TLC). The yellow pigment was resolved on the silica sheet with Rf value of 0.78 . The TLC fraction of the pigment was recovered by preparative TLC and the recovery was found to be $72 \%$. A number of pigmented compounds with bioactivity have been isolated from microorganisms. Pigments from Streptomyces sp particularly have attracted cancer biologist's worldwide (Soliev et al. 2011). Chinikomycin A, chinikomycin B and manumycin A compounds isolated from marine Streptomyces sp. M045are the pigmented antibiotics reported to possess anticancer property ( $\mathrm{Li}$ et al. 2005). We have found that the yellow pigment which gave positive for the presence of carotenoid from our Streptomyces strain JUACT01 exhibited profound anticancer potentials against HeLa and Hep G2 cells as indicated by their low $\mathrm{IC}_{50}$ concentrations (Table 1).

Table 1 - $\mathrm{IC}_{50}$ concentration of TLC purified yellow pigment on HepG2 and HeLa cells at 24, 48 and $72 \mathrm{~h}$ of treatment.

\begin{tabular}{ccc}
\hline Duration in h & $\begin{array}{c}\mathbf{I C}_{\mathbf{5 0}}(\boldsymbol{\mu g} / \mathbf{m l}) \\
\text { HePG }\end{array}$ & $\begin{array}{c}\mathbf{I C}_{\mathbf{5 0}}(\boldsymbol{\mu g} / \mathbf{m l}) \\
\mathbf{H e L a}\end{array}$ \\
\hline 24 & 26.33 & 5.31 \\
48 & 1.75 & 2.0 \\
72 & 1.41 & 1.8 \\
\hline
\end{tabular}

Working on a marine isolate of Streptomyces griseoaurantiacus strain MK393 Matsumoto et al. (1998) have identified an antitumor antibiotic called diperamycin. When tested for growth inhibitory potentials on various tumour cell lines, diperamycin had exhibited significant activity. The yellow pigment extract from JUACT 01 when tested for in vitro cytotoxicity on HeLa and Hep G2 cells by using MTT cell viability assay resulted in considerable inhibition of cell growth and proliferation. Conversely the yellow pigment did not show any toxic effect on normal lymphocytes. Microscopic observation revealed that the lymphocytic cell morphology was unaltered and growth and proliferation were unaffected even after $72 \mathrm{~h}$ of treatment (Fig. 3).

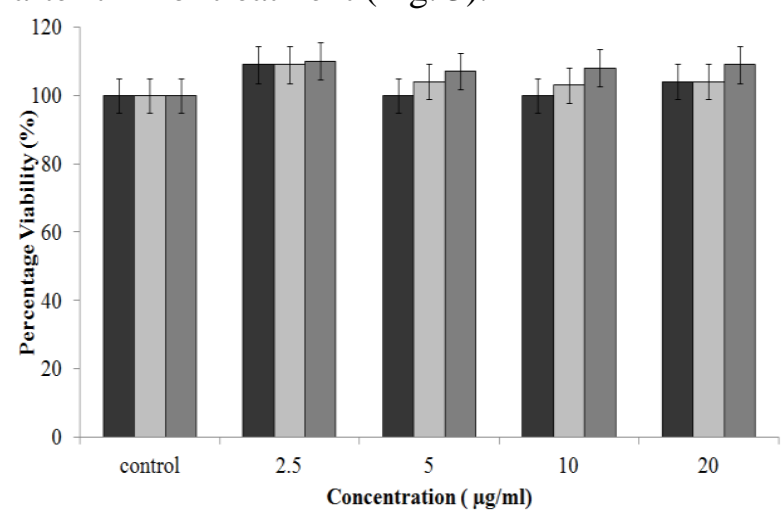

Figure 3 - Effect of yellow pigment on cell viability of human lymphocytes tested using MTT assay. Effect after $(\square) 24$ h, ( $\square) 48 \mathrm{~h}$ and $(\square) 72$ h.

Despite a number of drawbacks, novel apoptosis triggering drugs/approaches will enhance the development of innovative strategies in cancer therapy. DNA fragmentation is one of the notable biochemical changes occurring due to apoptosis (Huang et al. 1997). Appearance of discrete DNA fragments on conventional agarose gel is a clean evidence for the induction of apoptosis in the pigment treated cells. The DNA isolated from the cells treated with $20 \mu \mathrm{g} / \mathrm{mL}$ of pigment for $24 \mathrm{~h}$, was seen as a smear when compared to intact band of DNA isolated from untreated cells. Along with DNA degradation and increased caspase activity, cells undergoing apoptosis exhibit morphological changes like plasma membrane blebbing, cell body shrinkage and formation of membrane bound apoptotic bodies (Cohen et al. 1992). Microscopic observation of the cells after staining with $\mathrm{AO} / \mathrm{EtBr}$ stain enabled us to visualise the effect of pigment treatment on the morphology and viability of cancer cells (Telford et al. 1992). Typically viable cells were bright green in colour where as the dead ones were bright orange in colour (Fig. 4).

The treated cells appeared to be in apoptotic phase indicated by the presence of apoptotic bodies and nuclear condensation. Trypan blue cell counting demonstrated that the treatment caused lethal effect to a greater extent on the viable cancer cells. Percentage viability calculated by trypan blue cell counting indicated 2 and $6 \%$ cell viability after treating with the pigment for $24 \mathrm{~h}$ at $1 \mu \mathrm{g} / \mathrm{mL}$ concentration on HeLa and HepG2 cells respectively. Flow cytometric analysis of cell 
cycle with the recovered cells after treating with the pigment revealed that, there was a clear difference in the cell cycle stages between the untreated and treated cell populations of $\mathrm{HeLa}$ cells. It was seen that untreated cell population was healthy and multiplying with $40.27,32.31$ and $21.01 \%$ of cells in G1, S and G2 phase respectively. The treated cancer cell population showed least number of cells in S phase $(9.17 \%)$

(A)

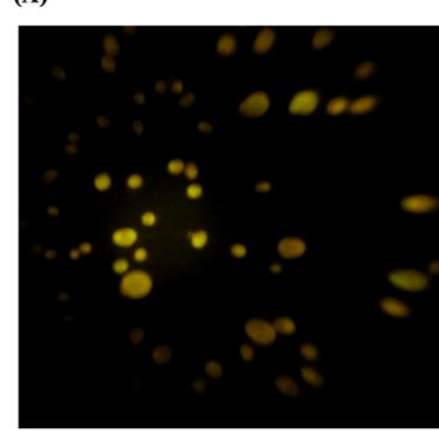

(B)

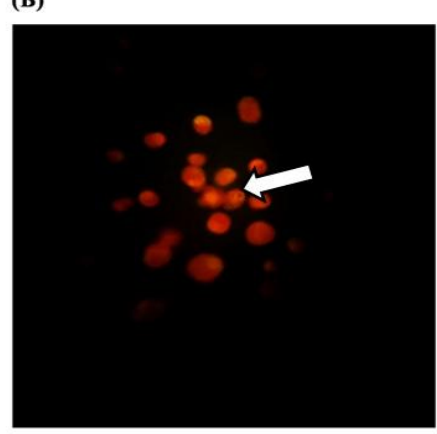

and fewer cells in G1 (32.78\%) and G2 (12.11\%) phase of the cell cycle indicating inhibition of proliferation. These results show the probable effect of pigment to cause apoptosis in the cancer cells. Activity of LDH present in the supernatant obtained by treating the cancer cells with 5.0 $\mu \mathrm{g} / \mathrm{mL}$ of purified yellow pigment was higher than the control samples demonstrating the cytotoxic effect of the pigment on cancer cell lines.

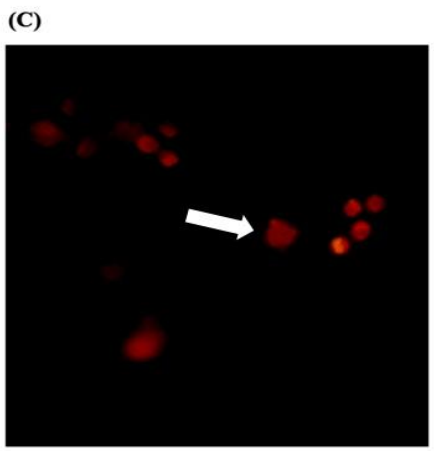

Figure 4 - Fluorescence microscopy photos (A) untreated cells (B) pigment treated HeLa cells (C) pigment treated HepG2 cells. The arrow indicates the fragmented DNA.

The activity obtained by the untreated cells was used to estimate maximum $\mathrm{LDH}$ released and the percentage activity was calculated for the control. The percentage cytotoxicity obtained by comparing the LDH activity between the positive, negative controls and the test samples was found to be $91 \%$ with HeLa cells and $111 \%$ with Hep G2 cells. Caspases are a family of aspertate- specific cysteine proteases that serve as the primary mediators of apoptosis. Also they are the early key indicators of apoptosis (Chang et al. 2000). The caspase activities measured show that there is a drastic increase in the activity of caspases in treated cells compared to the untreated cells with increase in time from $\mathrm{t}-0$ minutes to t- 45 minutes (Fig. 5).

Treatment with $5 \mu \mathrm{g} \mathrm{ml}-1$ concentration of the purified pigment on HeLa cells resulted in 1.6 fold increase in the final caspase activity as compared to the initial caspase activity whereas with Hep G2 cells the increase was found to be 2 folds. The percentage caspase activity values indicate that the treated HeLa and Hep G2 cells show $125.03 \%$ and $111.72 \%$ more caspase activity than the untreated cells at $\mathrm{t}-45$ minutes respectively. These results infer that the pigment treated cells indeed are undergoing apoptosis.
HPLC separation of the TLC fractionated pigment resulted in a major peak with a retention time of 9.90 minutes. The chromatograph shows no other major peaks indicating that the separation was ideal. Electro spray Ionisation Mass Spectrometry (ESI-MS) of the sample eluted at 9.90 minutes resulted with a peak showing $100 \%$ relative abundance corresponding to a mass to charge ratio $(\mathrm{m} / \mathrm{z}$ value) of 413.22 (Fig. 6).

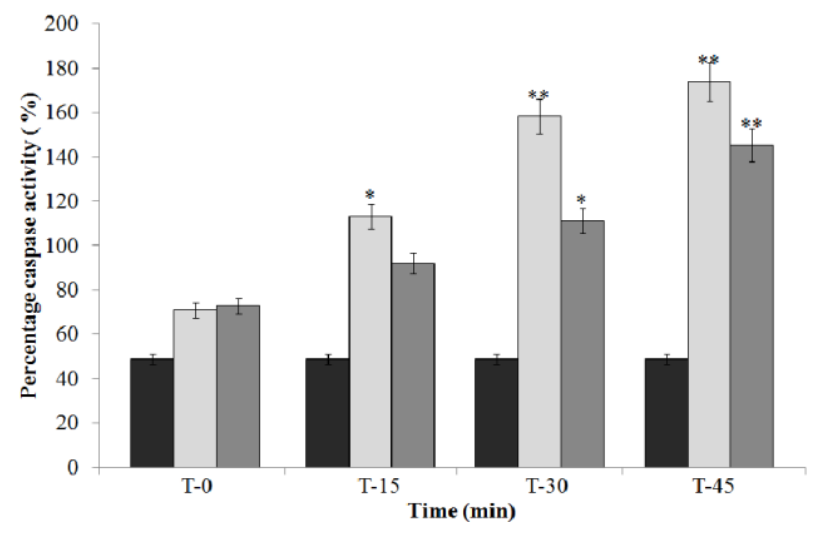

Figure 5 - Activity of caspases measured in ( $\square$ ) Control untreated cells, $(\square$ ) pigment treated HeLa cells and $(\square)$ pigment treated HepG2 cells from time T-0 min to T-45 $\min (* \mathrm{p}<0.05, * * \mathrm{p}<0.005)$. 


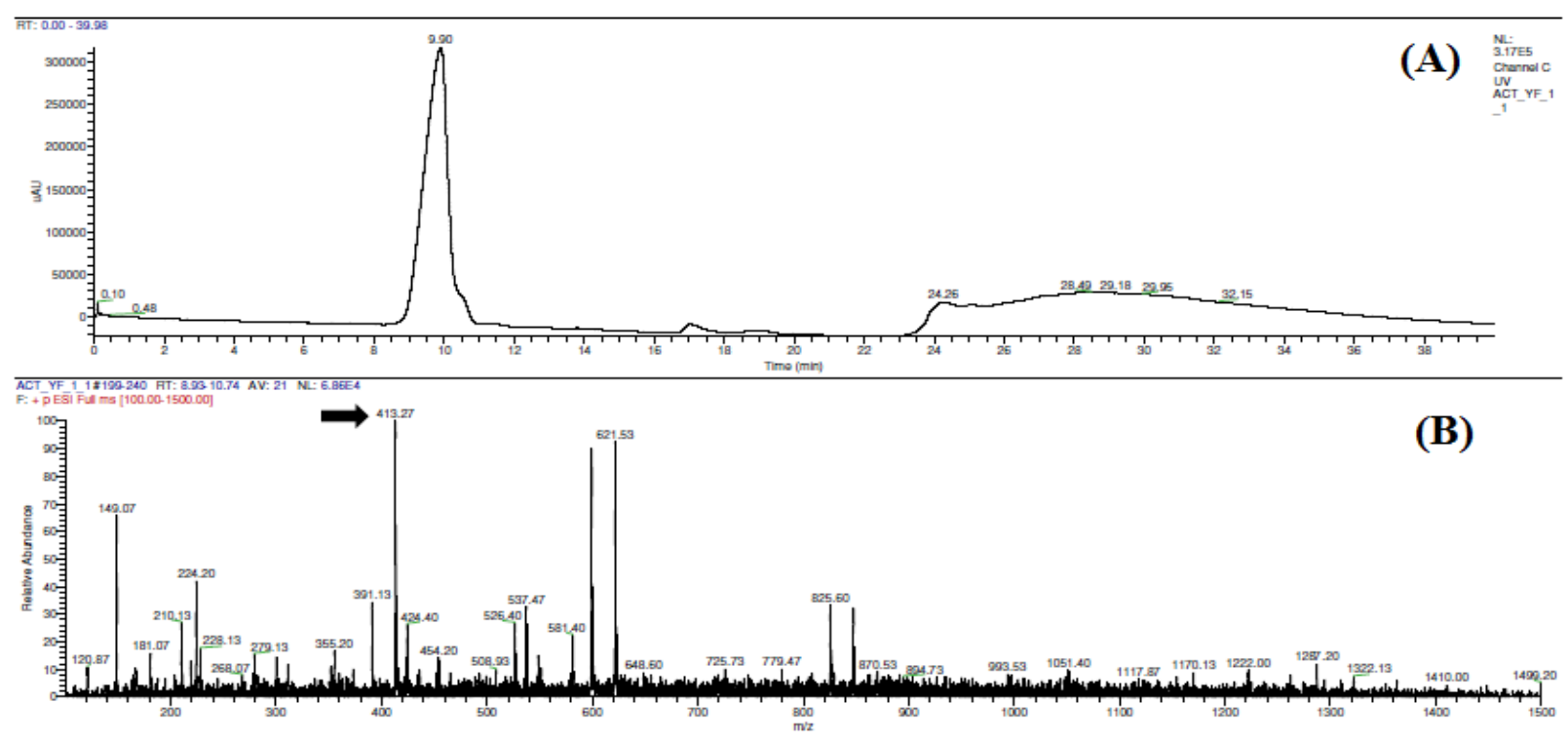

Figure 6 - HPLC and ESI-MS (A) HPLC chromatogram of TLC purified yellow fraction showing a major peak eluting at time $9.90 \mathrm{~min}$ (B) ESI- MS of HPLC fraction collected at time 9.90 min. Arrow indicates the $\mathrm{m} / \mathrm{z}$ of the pigment fraction as 413.27 showing $100 \%$ relative absorbance.

The IR spectrum for the TLC separated pigment showed characteristic absorption frequencies of hydroxyl group in alcohol or phenol group at 3313 $\mathrm{cm}^{-1}$, carbonyl group at $1640 \mathrm{~cm}^{-1}$, nitro group at $1294 \mathrm{~cm}^{-1}$ and vinyl group at $915 \mathrm{~cm}^{-1}$. The ESIMS and IR reports suggest that this kind of pigment with anticancer potentials was not reported from this species of Streptomyces and hence appears to be a novel one.

\section{CONCLUSION}

With these findings, we conclude that the yellow pigment from Streptomyces gresioaurianticus JUACT 01 isolated from soil has cytotoxic potential and is nontoxic to human lymphocytes. It inhibits the growth and proliferation of HeLa and HepG2 cells in vitro through induction of apoptosis. These results offer justification for further research to evaluate the structural features of the pigment molecule and its effect on specific cancer cell lines.

\section{ACKNOWLEDGMENTS}

The financial support by way of the grant provided by DST (project no. SR/SO/HS-0072/2012) is greatly acknowledged by the authors. The authors are grateful to the management of Jain Group of Institutions for the infrastructural facilities provided to carry out the work.

\section{REFERENCES}

Ajayi IA, Ajibade O, Oderinde RA. Preliminary phytochemical analysis of some plant seeds. Res $J$ Chem Sci. 2011: 1(3); 58-62.

Altschul SF, Gish W, Miller W, Myers EW, Lipman DJ. Basic local alignment search tool. J Mol Biol. 1990: 215(3): 403-410.

Berdy, J. Bioactive microbial metabolites. J Antibiot. 2005: 58(1); 1-26.

Chang HY, Yang X. Proteases for cell suicide: functions and regulation of caspases. Microbiol Mol Biol Rev. 2000: 64(4); 821-846.

Coates J. Interpretation of infrared spectra, a practical approach. In: Meyers RA, editor. Encyclopaedia of Analytical Chemistry. UK: John Wiley and Sons Ltd; 2000. p. 10815-10837.

Cohen GM, Sun XM, Snowden RT, Dinsdale D, Skilleter DN. Key morphological features of apoptosis may occur in the absence of internucleosomal DNA fragmentation. Biochem $J$. 1992: 286; 331-334.

Felsenstein J. Confidence limits on phylogenies: an approach using the bootstrap. Evol.1985:783-791. 
Ferlay J, Soerjomataram I, Ervik M, Dikshit R, Eser S, Mathers C, et al. Cancer Incidence and Mortality Worldwide: IARC CancerBase No. 11 [Internet]. 2013 [cited 2014 Dec.24] Lyon, France: International Agency for Research on Cancer. Available from: http://globocan.iarc.fr

Gomez A, Gomez A. A statistical procedure for agricultural research. 2. ed. Kwanchi: John Willy and Sons, 1984,188p.

Huang P, Ballal K, Plunkett W. Biochemical characterization of the protein activity responsible for high molecular weight DNA fragmentation during drug-induced apoptosis. Cancer Res. 1997: 57(16); 3407-3414.

Kirchner JG, Miller JM, Keller GJ. Separation and identification of some terpenes by new chromatographic technique. Anal Chem.1951: 23(3); 420-425.

Kirchner JG.Thin-layer chromatographic quantitative analysis. J Chromatogr A. 1973: 82(1); 101-115.

Li F, Maskey RP, Qin S, Sattler I, Fiebig HH, Maier A, et al. Chinikomycins A and B: Isolation, structure elucidation and biological activity of novel antibiotics from a marine Streptomyces sp. Isolate M045. J Nat Prod. 2005: 68 (3); 349-353.

Matsumoto N, Momose I, Umekita M, Kinoshita N, Chino M, Iinuma H et al. (1998). Diperamycin, a new antimicrobial antibiotic produced by Streptomyces griseoaurantiacus MK393-AF2. I. Taxonomy, fermentation, isolation, physico-chemical properties and biological activities. J Antibiot. 1998: 51(12); 1087-1092.

Mosmann T. (1983) Rapid colorimetric assay for cellular growth and survival: application to proliferation and cytotoxicity assays. J Immunol Methods. 1983: 65 (1); 55-63.

Nadumane VK, Venkat P, Pal A, Dharod H, Shukla M, Prashanthi K. A novel metabolite from Aspergillus ochraceus JGI 25 showing cytotoxicity to HeLa cells. Indian J Pharm Sci. 2013: 75 (5); 507.

Olano C, Méndez C, Salas JA. Antitumor compounds from marine actinomycetes. Mar Drugs. 2009: 7(2); 210-248.

Pozarowski P, Darzynkiewicz Z. Analysis of cell cycle by flow cytometry. In Checkpoint Controls and Cancer. Humana Press; 2004.p.301-311.
Saitou N, Nei M.The neighbour-joining method: a new method for reconstructing phylogenetic trees. Mol Biol Evol . 1987: 4(4); 406-425.

Sambrook J, Fritsch EF, Maniatis T. Molecular cloning.2.ed. New York: Cold spring harbor laboratory press, 1989,149p.

Schwieger F, Tebbe CC. A new approach to utilize PCR-single-strand-conformation polymorphism for 16S rRNA gene-based microbial community analysis. Appl Environ Microbiol. 1998: 64(12);4870-4876.

Seidel V. Initial and bulk extraction. In Natural products isolation. 2005, Humana Press. p.27-46

Selvameenal L, Radhakrishnan M, Balagurunathan R. Antibiotic pigment from desert soil actinomycetes; biological activity, purification and chemical screening. Indian J Pharm Sci. 2009: 71(5); 499.

Shirling EB, Gottlieb D. Cooperative description of type cultures of Streptomyces. II. Species descriptions from first study. Int J Syst Bacteriol. 1968:18(2); 69189.

Snyder LR, Kirkland JJ, Glajch JL. Practical HPLC method development.2012, John Wiley and Sons.

Solanki R, Khanna M, Lal R. Bioactive compounds from marine actinomycetes. Indian $J$ Microbiol. 2008:48(4); 410-431.

Soliev AB, Hosokawa K, Enomoto K. Bioactive pigments from marine bacteria: applications and physiological roles. Evidence-Based Complementary and Altern Med. 2011: 2011(2011); 17.

Tamura K, Peterson D, Peterson N, Stecher G, Nei M, Kumar S. Molecular evolutionary genetics Analysis using maximum likelihood, evolutionary distance, and maximum parsimony methods. Mol Biol Evol. 2011: 28(10); 2731-2739.

Telford WG, King LE, Fraker PJ. Comparative evaluation of several DNA binding dyes in the detection of apoptosis-associated chromatin degradation by flow cytometry. Cytometry. 1992: 13(2); 137-143. 